\title{
Impact of organic and inorganic fertilizers on the growth and yield of cabbage in Ghana
}

\author{
Asomah S., Anankware, J. P., Adjei, R. R. \\ Department of Horticulture and Crop Production, School of Agriculture and Technology, \\ University of Energy and Natural Resources, P.O. Box 214, Sunyani-Ghana \\ Author for correspondence: shadrack476@gmail.com
}

\begin{abstract}
Summary: A field experiment was conducted at Dormaa Ahenkro, Ghana, to determine the impact of inorganic and organic fertilizers on the growth and yield of cabbage. The experiment was laid in a randomized complete block design with three replications. The experiment treatment comprises of sole application of poultry manure (PM), NPK 15:15:5, the combined application of poultry manure and NPK fertilizer (PM+NPK) and the control (no fertilizer). Data was collected on the number of leaves, stem girth, plant height, head diameter, head weight and edible head weight. There was a significant difference $(\mathrm{P}<0.05)$ among all the treatments. The combined application of PM+NPK recorded the highest values for all the parameters measured. From the results obtained farmers should consider the combined application of PM and NPK to maximize yield on their farm.
\end{abstract}

Asomah S., Anankware, J. P., Adjei, R. R. (2021): Impact of organic and inorganic fertilizers on the growth and yield of cabbage in Ghana. International Journal of Horticultural Science 27: 46-49. https://doi.org/10.31421/ijhs/27/2021/8923

Key words: poultry manure, head weight, plant height, cabbage, organic fertilizer

\section{Introduction}

Cabbage (Brassica oleracea var. capitata) is one of the most important vegetables in the world. It is grown on five continents and in more than 90 countries throughout the world. It was originated from Western Europe and the Western Mediterranean where it grows on ledges of chalky cliffs where most plants can't survive (Nieuwhof, 1969), and is counted to be one of the most important vegetable crops in the human and animal diet because of its nutritional value (Lešić et al., 2004). Apart from using it as a food or feed source, cabbage is being used for manufacturing medicine. Cabbage offers long-term health benefits to consumers where it contributes to the fight against cancer. Kang et al. (2006) added that regular consumption of glucosinolates from cabbage reduces one's chance of cancer induction and development.

The production of cabbage recently in Ghana is confronted with numerous problems, which include; high cost of inputs, less productive soils and unfavourable weather conditions.

A study conducted by Appiah (2015) reported that soilnutrient capital is gradually depleting since farmers are not able to compensate losses by returning nutrients to the soil via crop residues, manures and mineral fertilizers. The application of fertilizers helps to enhance plant growth by providing amendments to the soil via various macro-and micronutrients. Stockdale \& Watson (2009) also noted that soil fertility and quality is linked with the biological activity which is a very important aspect of crop production. Improper fertilizer type and rate of application are some of the major constraints that limit the performance of crops (Ngegba et al., 2020). To satisfy consumers requirements, the use of appropriate fertilizer creates the headway (Nagy, 2009).

Many farmers in Ghana lack the technical knowledge of choosing and applying appropriate fertilizer to their crops. No attention has been paid to the combination of organic and inorganic fertilizer and its effects on the growth and yield attributes of cabbage (Mebrahtu \& Solomun, 2018).

The application of organic fertilizers improved water holding capacity, availability of nutrients maintains $\mathrm{C}: \mathrm{N}$ ratio increases the macro/micronutrient content and crop yields, size, flavour, aroma, and quality (Timsina, 2018). Despite these tremendous benefits, the yields of crops treated with organic fertilizers are $20 \%$ less than that of inorganic (Santhoshkumar et al., 2017; Ramesh et al., 2020). These limitations call for the adoption of combining organic and inorganic fertilizers.

Integrated nutrient management of fertilizers (organic or inorganic) has proven to be an efficient way to sustain yields, improve the soil physical and chemical properties and improve crop nutrient intake (Tandon, 1995).

This study, therefore, aimed to investigate the impact of organic and inorganic fertilizers on the growth and yield of cabbage.

\section{Materials and methods}

The experiment was conducted during the raining season at the Model School Farm of the School of Agriculture and Technology, University of Energy and Natural Resources, Dormaa-Ahenkro which is located in the western part of the Bono Region. A randomized complete block design was usedfor the field experiment to avoid bias on the treatment and was replicated three times. The experimental site was cleared, ploughed, harrowed and divided into different plots. Each treatment plot measured $1.2 \mathrm{~m} \times 1.6 \mathrm{~m}$ with a total plot area of $53.04 \mathrm{~m}^{2}$. The surface soil $(0-20 \mathrm{~cm})$ is sandy loam. The total monthly precipitation and monthly average air temperature of 
the experimental site are shown in Figure 1. The treatments were: control, NPK (15:15:15), poultry manure and a combination of NPK and poultry manure. The chemical composition of the poultry manure is as follows: $3.52 \% \mathrm{~N}$, $0.86 \% \mathrm{P}$ and $1.83 \% \mathrm{~K}$.

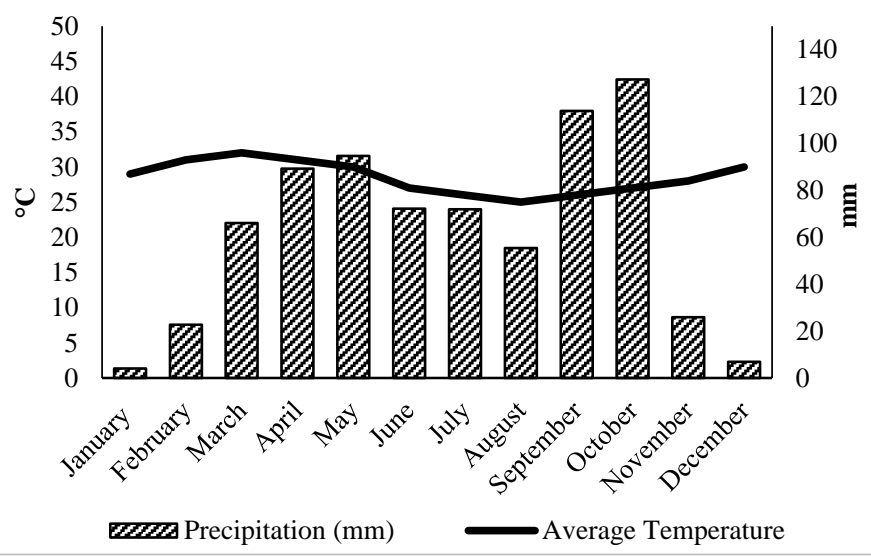

Figure 1: Total monthly precipitation and monthly average air temperature (2017)

The organic fertilizer (poultry manure) was applied at the rate of $40 \mathrm{t} / \mathrm{ha}$ whilst inorganic (NPK) was applied at a rate of $250 \mathrm{~kg} / \mathrm{ha}$ as recommended by Dumičić et al. (2014) and MoFA (2008), respectively. The organic fertilizer was incorporated into the soil using a hand trowel one week before transplanting the seedlings to enable decomposition of the organic matter whereas the inorganic fertilizer was applied one week after transplanting of the cabbage seedlings. The fertilizer was broadcasted on the field. Oxylus cabbage variety was used. Seedlings were transplanted two weeks after nursing at a spacing of $40 \mathrm{~cm} \times 40 \mathrm{~cm}$ between and within rows. Each replication consisted of 20 plant stands where 5 healthy plants were randomly selected and tagged for data collection. Data were collected on the physiological growth parameters (plant height $(\mathrm{cm})$, stem girth and leaf number) two weeks after transplanting (WAT) throughout to eight WAT. The number of leaves was counted from each green and functional leaf that existed on the plant at each sampling time. The plant height was measured from $2 \mathrm{~cm}$ from ground level to the tip of the plant using a ruler. Yield data were taken on the following parameters: harvested head weight, head diameter and edible head weight. The head weight was measured with the help of a digital scale in grams $(\mathrm{g})$, the head diameter was also measured with the vernier caliper in centimetres $(\mathrm{cm})$.

Data were arranged with Microsoft Excel and statistically analyzed to find out the significant difference with analysis of variance (ANOVA) using GenStat Discovery Edition $12^{\text {th }}$ to separate the means at a $5 \%$ probability level.

\section{Results and discussion}

\section{Effect of inorganic and organic fertilizer on the growth of cabbage}

\section{Plant height}

The effect of poultry manure (PM), inorganic fertilizer and their combination on the plant height of cabbage has been presented in Figure 2. There was no significant difference (P>0.05) among the fertilizer treatments at 2 WAT for plant height. The cabbage plants treated with the combination of PM and NPK recorded the highest plant height $(9.05 \mathrm{~cm})$ followed by NPK fertilizer $(8.43 \mathrm{~cm})$. The shortest plant height was recorded by the control in which no fertilizer was applied $(6.37$ $\mathrm{cm})$. Significant differences $(\mathrm{P}<0.05)$ were detected among the treatments for 4, 6 and 8 WAT. The combination of PM and NPK recorded the highest plant height of $13.02 \mathrm{~cm}, 17.79 \mathrm{~cm}$ and $21.92 \mathrm{~cm}$ for 4,6 and 8 WAT, respectively. The lowest plant height was recorded by the plots with no fertilizer treatment of $8.39 \mathrm{~cm}, 11.89 \mathrm{~cm}$ and $15.43 \mathrm{~cm}$ for 4,6 and 8 WAT respectively (Figure 2). It should be noted that there was no significant difference between the PM and the NPK treatments. From the results obtained it is evident that the combined application of PM and NPK affects the plant height of the cabbage plant. According to studies conducted by Prasithikhet et al. (1993), the combined application of inorganic and organic fertilizers is more effective in increasing the productivity of a crop than they are used separately. A similar finding was also observed by Sumaila (2019) who indicated that the application of both organic and inorganic fertilizers combined can increase the growth, yield as well as keep the environment sound. Santhoshkumar et al. (2017) also observed a significant difference among the treatments in their study.

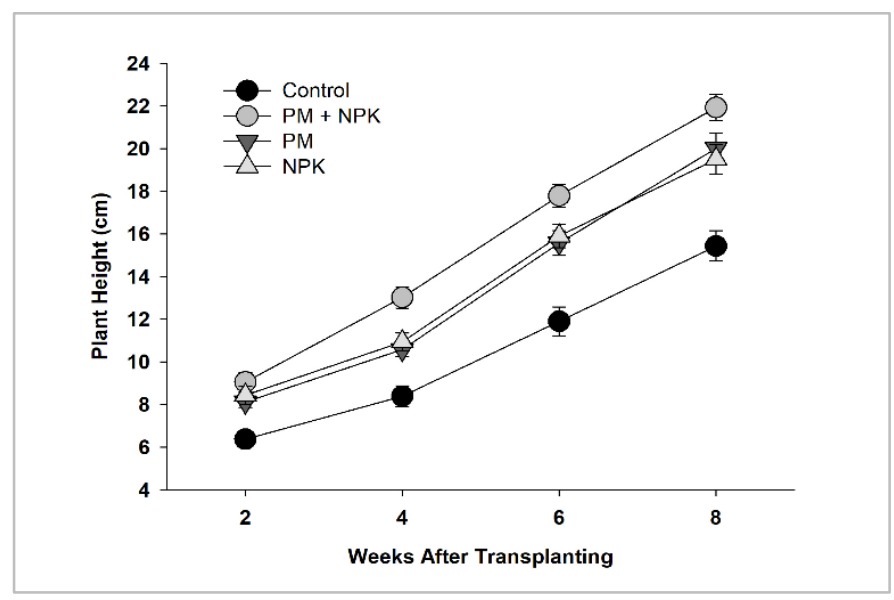

Figure 2: Effect of inorganic and organic fertilizer on plant height $(\mathrm{cm})$ of cabbage

\section{Number of leaves}

A significant difference $(\mathrm{P}<0.05)$ was observed among the treatments for the number of leaves at 2, 4, 6, 8 WAT. The combination of PM + NPK recorded the highest number of leaves followed by the cabbage plants treated with PM only at 2, 4, 6, 8 WAT (Figure 3). The findings of this study corroborate the results of Khadir et al. (2002) who also observed that the combined application of different inorganic and organic fertilizers increased both vegetative and leaf number in cabbage. A similar finding was also reported by Sharma (2000) and Mebrahtu \& Solomun (2018).

\section{Stem girth}

Regarding the stem girth, a significant difference $(\mathrm{P}<0.001)$ was observed among the treatments for 2, 4, 6 and 8 WAP. The combination of the PM and NPK fertilizer performed better than the sole application of the PM and NPK fertilizer as seen in Figure 4. 


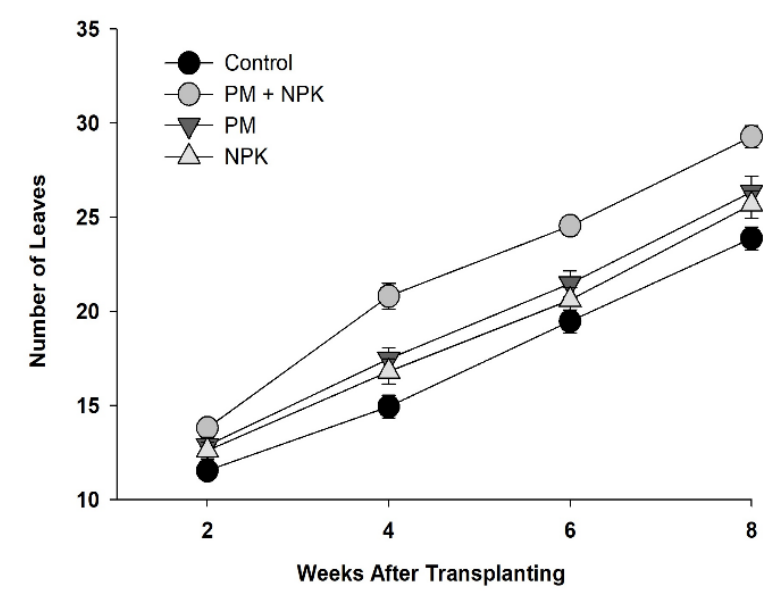

Figure 3: Effect of inorganic and organic fertilizer on the number of leaves of cabbage

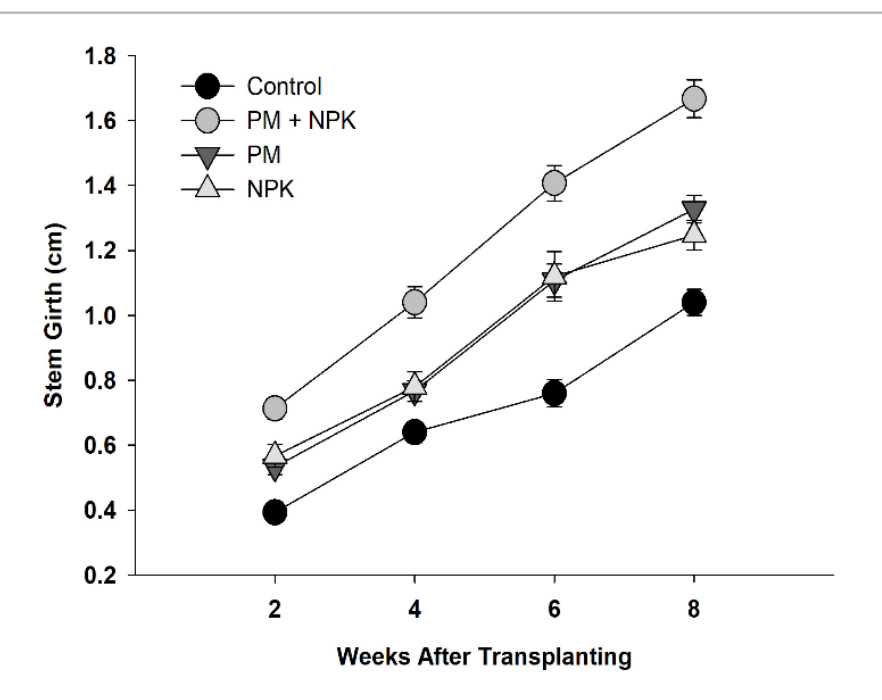

Figure 4: Effect of inorganic and organic fertilizer on the stem girth of cabbage

Effect of inorganic and organic fertilizer on the yield of cabbage

\section{Head diameter $(\mathrm{cm})$}

The head diameter of the cabbage was significantly influenced $(\mathrm{P}<0.05)$ by the application of the different fertilizers. The combined application of PM and NPK recorded the highest head diameter $(11.33 \mathrm{~cm})$, followed by the sole application of PM and was significantly different from the control $(8.86 \mathrm{~cm})$ which recorded the smallest head diameter (Table 1). Similar results were observed by Mebrahtu \& Solomun (2018), Haque (2012) and Kedino et al. (2009) who reported higher head diameter with the combined application of organic and inorganic fertilizers in their study.

\section{Harvested head weight $(g)$}

A significant difference $(\mathrm{P}<0.05)$ was observed among the fertilizer treatments. The highest harvest head weight was recorded by PM + NPK (1465.0 g) treated cabbage plants followed by PM (1213.3 g), and NPK (1212.9 g) as compared to the control which recorded the least harvested head weight (816.3 g) (Table 1).

\section{Edible head weight $(g)$}

The edible head weight showed a statistically significant difference $(\mathrm{P}<0.05)$ among the treatments (Table 1). The combined application of PM + NPK recorded the maximum edible head weight ( $940.4 \mathrm{~g})$ was superiorly significant over the other treatments. The minimum edible head weight was recorded by the control plot $(374.4 \mathrm{~g})$.

Table 1: Effect of inorganic and organic fertilizers on the head diameter

harvested head weight $(\mathrm{g})$ and the edible head weight $(\mathrm{g})$ of cabbage

\begin{tabular}{lccc}
\hline Treatment & $\begin{array}{c}\text { Head } \\
\text { diameter }(\mathbf{c m})\end{array}$ & $\begin{array}{c}\text { Harvested head } \\
\text { weight }(\mathbf{g})\end{array}$ & $\begin{array}{c}\text { Edible head } \\
\text { weight }(\mathbf{g})\end{array}$ \\
\hline Control & $8.86 \pm 0.97^{\mathrm{a}}$ & $816.3 \pm 129.0^{\mathrm{a}}$ & $374.4 \pm 112.2^{\mathrm{a}}$ \\
NPK & $9.76 \pm 0.78^{\mathrm{b}}$ & $1212.9 \pm 273.6^{\mathrm{b}}$ & $680.8 \pm 324.5^{\mathrm{b}}$ \\
$\mathrm{PM}$ & $9.79 \pm 0.86^{\mathrm{b}}$ & $1213.3 \pm 247.6^{\mathrm{b}}$ & $634.1 \pm 216.5^{\mathrm{b}}$ \\
$\mathrm{PM}+\mathrm{NPK}$ & $11.33 \pm 0.81^{\mathrm{c}}$ & $1465.0 \pm 505.0^{\mathrm{b}}$ & $940.4 \pm 296.3^{\mathrm{c}}$ \\
\hline
\end{tabular}

Means $( \pm \mathrm{SD})$ with different letters in columns differ significantly

\section{Conclusions}

Findings from the study indicate that the combined application of NPK + PM increased significantly the growth and yield of cabbage for all the parameters measured. Thus it can be recommended for enhancing growth and yield in cabbage.

\section{References}

Appiah, G. F. (2015): Effect of poultry and inorganic manure (NPK 15: 15: 15) on growth, yield and shelf life of tomato (Lycopersicon esculentum Mill.) (Doctoral dissertation).

Dumičić, G., Díaz-Pérez, J. C., Sidhu, H. S., Urlić, B., Ban, S. G., MacLean, D., Workman, S. (2014): Kale (Brassica oleracea L. var. acephala DC) leaf water loss as affected by genotype and bagging. 49. hrvatski i 9. međunarodni simpozij agronoma, 16. do 21. veljače 2014, Dubrovnik, Hrvatska. Zbornik Radova. 305-309.

Haque, A. (2012): Effect of Different Organic Manures on Growth and Yield of Cabbage. Master's Thesis, Department of Horticulture, Patuakhali Science and Technology University (PSTU), Dumki, Patuakhali. Bangladesh 1-73.

Kang, J. Y., Ibrahim, K. E., Juvik, J. A., Kim, D. H., Kang, W. J. (2006): Genetic and environmental variation of glucosinolate content in Chinese cabbage. HortScience, 41(6), 1382-1385. https://doi.org/10.21273/HORTSCI.41.6.1382

Kedino, Z., Kanaujia, S. P., Singh, V. B., Singh, P. K. (2009): Effect of organic manures and biofertilizers on growth, yield, quality of cabbage (Brassica oleracea var. capitata) under foot hill condition of Nagaland. Environment and Ecology. 27(3): 1127-1129.

Khadir, G. A., Marazat, S. K., Sadoun, S. A. (2002): Effect of different levels of urea fertilizers and plant spacing on growth and yield of cabbage. Dirasat 16: 88-105.

Lešić, R., Borošić, J., Buturac, I., Herak Ćustić, M., Poljak, M., Romić, D. (2004): Povrćarstvo.

Mebrahtu, M., Solomun, M. (2018): The Combined Effect of Organic and Inorganic Fertilizer on Yield and Yield 
Component of Cabbage (Brassica oleracea) at Dedebit Central Tigray, Ethiopia. Journal of Plant Science in Crop Protection. 1(2): 202.

MoFA (2008): Ministry of Food and Agriculture. https//www.mofa.gov.gh

Nagy, P. T. (2009): Gyümölcsösök tápanyag-gazdálkodásának időszerü kérdései. Debreceni Egyetem, Agrár-és Müszaki Tudományok Centruma, Kutatási és Fejlesztési Intézet. 248. p.

Ngegba, P. M., Kanneh, S. M., Quee, D. D. (2020): Assessment of different rates of NPK fertilizer on the growth and yield components of two exotic okra (Abelmoschus esculentus L.) western urban of Sierra Leone. International Journal of Horticultural Science. 26. 55-59. https://doi.org/10.31421/IJHS/26/2020/5439

Nieuwhof, M. (1969): Cole crops. Cole crops.

Prasithikhet, J., Mongkolporn, P., Sritanan, V., Sonmuang, P. (1993): Use of organic and inorganic fertilizers in farmers' rice fields in the Northeast. Soil Management Abstracts. 5(2).1458.

Ramesh, E., Sikder, S., Basfore, S. (2020): Bio-effectiveness of Sabuj Gold as organic manure on cabbage, cauliflower and French bean. Current Journal of Applied Science and Technology, 30-36. https://doi.org 10.9734/CJAST/2020/ v39i2930954
Santhoshkumar, M., Reddy, G. C., Sangwan, P. S. (2017): A review on organic farming-Sustainable agriculture development. International Journal of Pure and Applied Bioscience. 5(4): 1277-1282.

Sharma, K. C. (2000): Influence of integrated nutrient management on yield and economics in broccoli (Brassica oleracea L. var italica Plenck) under cold temperate conditions. Vegetable Science. 27(1): 62-63.

Stockdale, E. A., Watson, C. A. (2009): Biological indicators of soil quality in organic farming systems. Renewable Agriculture and Food Systems. 24(4): 308-318. https://doi.org/10.1017/S1742170509990172

Sumaila, I. (2019): Organic manure and inorganic fertilizer effect on the growth and yield of cabbage (Brassica oleracea var. capitata) and incidence of insect pest in the forest transition zone of Ghana (Doctoral dissertation, University of Education, Winneba).

Tandon, H. L. S. (1995): Major nutritional constraints to crop production and the soil fertility management strategies in different agroclimatic regions of Asia. Basel, Switzerland: International Potash Institute (43-72).

Timsina, J. (2018): Can organic sources of nutrients increase crop yields to meet global food demand? Agronomy. 8(10): 214. 